\title{
Growth pattern, condition factor, trace metal studies and ectoparasitic load of the blue crab, Callinectes amnicola from Lagos Lagoon, Badore, Ajah, Lagos, Nigeria
}

\author{
Ukperhine OMUVWIE and Oluwatosin E. ATOBATELE *
}

Department of Biological Sciences, Bowen University, P.M.B. 284, Iwo, Osun State, Nigeria.

* corresponding author e-mail: tosine_ben@yahoo.com

\begin{abstract}
Aspects of the biology of an economically important crab, Callinectes amnicola (De Rochebrune, 1883), were studied to determine the growth pattern, condition factor, ectoparasitic load and trace metal (Manganese, Zinc, Lead, Cadmium and Mercury) levels. Water and sediment samples were also collected for trace metal analysis and to determine bioconcentration factor in crab samples. Males recorded significantly longer carapace $(p<0.05)$ and were heavier $(p<0.01)$ compared to female crabs. C. amnicola showed negative allometric growth $(p<0.05$; $b<3$ ) regardless of sex or size using carapace width; however, with carapace length, the crab exhibited isometric growth for male $(p>0.05 ; b=3)$ and positive allometric growth for female and sex combined $(p<0.05 ; b>3)$. Males were better conditioned than females and condition increased with size for males. Only male $C$. amnicola were infected with ectoparasitic barnacles with a prevalence of $13.46 \%$. The ectoparasites select better conditioned crabs for infestation and this colonization subsequently reduces the condition with increased size. Mean trace metal values recorded for C. amnicola, water and sediment were in the order Manganese $>$ Zinc $>$ Lead $>$ Cadmium $>$ Mercury. The gills had the highest mean values for all the trace metals measured and also had the highest bioconcentration factor with lead recording a factor of 42 from water. However, the edible portion such as muscle, chelipeds and carapace bioaccumulated Manganese, Zinc and Cadmium from water by a maximum factor of 4 . Carapace length, growth pattern, condition factor and ectoparasitic infestation may be used to discriminate among sexes of $C$. amnicola. This study shows relatively low concentrations of trace metals compared to the WHO limits and $\mathrm{C}$. amnicola may be used to monitor the bioavailability of trace metals in the Lagos Lagoon.

Key words: bioconcenteration factor, Callinectes amnicola, condition factor, ectoparasites, trace metals.
\end{abstract}

\section{Introduction}

The big fisted swim crab or blue crab, Callinectes amnicola (Rochebrune 1883), is an economically important crab common in the estuarine environments of West Africa [1] and serves as a source of protein and mineral ions. It plays critical roles in the aquatic food web as voracious, opportunistic predator, and is an important source of prey for many different species [2]. A description of the morphology of $C$. amnicola has been given by [3]. C. amnicola is reported to be the most abundant crustacean in Abule Agege Creek (around Lagos Lagoon), Lagos [4]. The crab is reported to exhibit great fishery potential especially during the rainy season and is a potential candidate for aquaculture [5]. Literature on the biology of $\mathrm{C}$. amnicola in Nigerian water bodies has increased in recent years. Studies have been carried out on
Badagry, Lagos and Lekki lagoons and surrounding creeks [1; 4; 6- 9]; Okpoka Creek, Niger Delta [3; 10-13]; lower reaches of Warri River [5] and Imo River Estuary [14]. C. amnicola is regarded as an opportunistic omnivore (detritus feeder and predator) [5] and [8]; and as an opportunistic benthic predator [11; 12]. Crustaceans, fish, molluscs and annelids are important food items of the crab [7] and [8]. Significant changes in food habits relative to size of crabs and this has been attributed to prey size selectivity [12]. Lawal-Are [8] opined that the similarity in food habits of the crabs from the Badagry, Lagos and Lekki lagoons indicate the occurrence of intraspecific competition which has resulted in a wide selection of food items. Callinectes is also a food item of Liza falcipinnis [15]. UabolEgbenni et al. [16] isolated and characterised pathogenic bacteria in the gut of Callinectes. 
C. amnicola is reported to exhibit tide dependent migration into mangrove swamps [17]. Abowei et al. [13] reported excessive fishing pressure due to human exploitation of C. amnicola in Okpoka Creek and opines that this is not sustainable. [3] reported relatively larger size of $C$. amnicola from Southwest Nigeria compared to Okpoka Creek, Niger Delta as a result of high fishing mortality.

The objectives of this study are to determine the growth pattern and condition factor for both sexes and sexes combined; ectoparasitic load, heavy metal concentration and bioconcentration factor (BCF) values in different organs and size groups of Callinectes amnicola.

\section{Materials and Methods}

Freshly caught crab samples were bought from the market at the river side at Badore, Lagos State, and were transported to the laboratory in polythene buckets. The crab specimens were killed in a dessicator containing chloroform for about 5-10mins. The total body weight (W) of each crab was measured to the nearest $0.1 \mathrm{~g}$ using a weighing balance while the carapace length $(\mathrm{CL})$ was measured with a ruler to the nearest $0.1 \mathrm{~cm}$. The male and female sexes were identified after barnacles on the crabs were removed using a spatula [18]. The location and abundance of individual barnacle on each crab were recorded.

The length-weight relationship was estimated using the Equation: $W=a L^{b}$, where $W$ is the weight, $a$ is the intercept, $C L$ is carapace length and $b$ is the slope. The values of $a$ and $b$ were computed from the log transformed values of carapace length and weight, i.e. Log $\mathrm{W}=\log \mathrm{a}+\mathrm{b} \log \mathrm{CL}$; where $\mathrm{W}=$ weight $(\mathrm{g})$ of the crabs, $\mathrm{CL}=$ horizontal carapace length $(\mathrm{cm})$, using the linear regression analysis routine of GenStat-Seventh Edition (DE3) Service Pack 1, version 7.2.2.222 (2008). The Fulton's condition factor was calculated according to Bagenal [19] with the formula: $K$ $=100 \mathrm{~W} / \mathrm{CL}^{\mathrm{b}}$; where $\mathrm{K}$ is the condition factor, $\mathrm{W}$ is the total body weight, $\mathrm{CL}$ is the carapace length and $b$ is the regression (growth) coefficient.

Dissection of the organs and tissues were carried out using stainless steel tools to prevent contamination. The crabs were grouped into three size-classes, according to carapace width: $8.5 \mathrm{~cm}-11.5 \mathrm{~cm}$ size group, $11.6-13.5 \mathrm{~cm}$ size group, and $13.6-16.5 \mathrm{~cm}$ size group. The carapace, gills, body muscle, gonads and cheliped from each size class were removed. Each crab sample was dried in an oven at $105^{\circ} \mathrm{C}-110^{\circ} \mathrm{C}$ for $24 \mathrm{~h}$ or until the weight was stable and later cooled in desiccators. The grouped crab samples were grounded manually to powder with a pretreated wooden mortar and pestle, which were cleaned after each crushing to avoid contamination [20], and kept in sealed prewashed and labeled petridishes.

Three grams of each prepared sample were weighed and digested using a 10:1 ratio of $55 \%$ nitric acid and $70 \%$ perchloric acid until a clear solution was obtained [21; 22]. The samples were cooled, filtered through Whatman $9.0 \mathrm{~cm}$ qualitative filter paper and diluted to $100 \mathrm{ml}$ with distilled water. The samples were stored in sampling bottles which were thoroughly washed with a solution of $5 \%$ nitric acid and distilled water to avoid contamination. Water and sediment samples for trace metal analyses were collected from Lagos Lagoon, Badore, in pretreated plastic bottles; while sediment samples were collected in pretreated polythene bags and taken to the laboratory for analyses. Water samples were acidified with $55 \%$ nitric acid and filtered through Whatman qualitative filter paper, thereafter each sample was diluted to $100 \mathrm{ml}$ with distilled water and kept at $6^{\circ} \mathrm{C}$. Sediment samples were dried at $100^{\circ} \mathrm{C}$ for $24 \mathrm{~h}$ until weight stabilized, after which each sample was sieved to obtain a homogenous sample. This was then finely grounded with a mortar and pestle, then $1 \mathrm{~g}$ of sample was digested with 1:1 ratio of $55 \%$ nitric acid and $32 \%$ hydrochloric [23]. The samples were allowed to cool only after a clear solution was obtained and filtered through Whatman $9.0 \mathrm{~cm}$ qualitative filter papers and the filtrate was diluted to $100 \mathrm{ml}$ with distilled water and stored. The concentrations of trace metals in various samples were determined by an atomic absorption spectrophotometer. Bioconcenteration factor was calculated for whole crabs and body parts for each metal. The formula used to calculate the BCF [24] is 
$\mathrm{BCF}=$ metal in crab sample /metal in water sample giving an indication of the degree of trace metal accumulation in the crab from the water $\left(\mathrm{BCF}_{\mathrm{w}}\right)$ and sediment $\left(\mathrm{BCF}_{\mathrm{s}}\right)$.

\section{Results}

Male crabs had narrow abdomen with the absence of pleopods while the females had a wider abdomen with the pleopods retained (Plate 1). Sex ratio recorded was 1:0.63 and shows that males and females are equally abundant $\left(X^{2}=2.76 ; P>0.05\right)$. Carapace length, width and weigth for $C$. amnicola ranged from $3.50 \mathrm{~cm}$ to $7.00 \mathrm{~cm}$ (mean $=$ $5.61 \pm 0.10 \mathrm{~cm}), 7.50 \mathrm{~cm}$ to $15.00 \mathrm{~cm}$ (mean $=$ $12.26 \pm 0.25 \mathrm{~cm}$ ) and $19.80 \mathrm{~g}$ to $190.30 \mathrm{~g}$ (mean $=109.93 \pm 6.06 \mathrm{~g})$ respectively (Table 1$)$. The mean carapace length and weight showed significant difference between the sexes at $p<0.05$ and $p<0.01$ respectively, however carapace width showed similarity among the sexes.

The $b$ estimate, from carapace length $(C L)$ and weight $(W)$, for male (2.98) showed isometric growth $\left(\mathrm{t}_{31}=0.74 ; \mathrm{p}>0.05 ; \mathrm{b}=3\right.$ ) (Table2); however, for female (3.05) and sex combined (3.12), it showed positive allometry $\left(t_{19}=2.37 ; p<0.05 ; b>3\right.$ and $t_{51}=7.28$; $p<0.05 ; b>3$ respectively). The $b$ estimate, from carapace width (CW) and weight (W), for male (2.95), female (2.57) and sex combined (2.81) showed negative allometry $(p<0.05 ; b<$ 3) (Table 3).

Male C. amnicola were better conditioned than females with mean values of $64.05 \pm 2.37$ and $50.64 \pm 1.71$ respectively. Males recorded a significantly higher condition factor for size classes $11.6-13.5 \mathrm{~cm}(68.00 \pm 2.85)$ and 13.6$16.5 \mathrm{~cm}(64.37 \pm 3.85)$ compared to size class $8.5-11.5 \mathrm{~cm} \quad(49.99 \pm 6.22)$; however, the condition factors for females were regardless of size (Figure 1). For combined sexes, the mean condition factor for size class 11.6$13.5 \mathrm{~cm}(51.48 \pm 1.76)$ is significantly higher than that of size class $8.5-11.5 \mathrm{~cm}$ (42.81 \pm 2.62$)$.

Ectoparasitic barnacles were recovered from the carapace (Plate 2a), chelipeds (Plate 2b) and walking legs of $C$. amnicola. Only the male crabs were infected with a prevalence of $13.46 \%$.
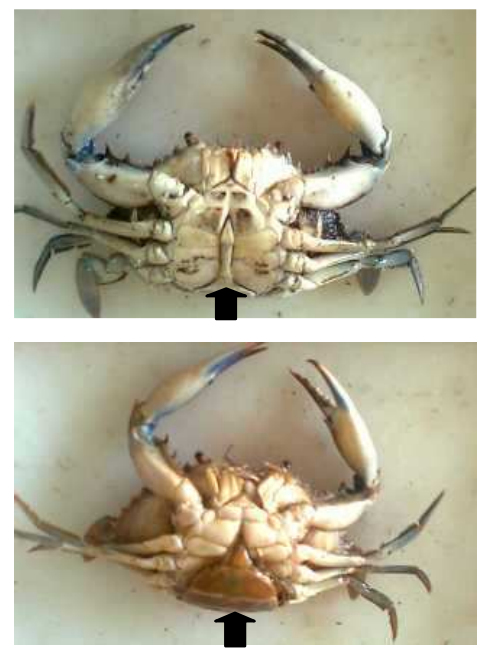

Plate 1: Male (narrow abdomen) and female (broad abdomen) Callinectes amnicola.

Table 1: Carapace length $(C L)$, carapace width $(\mathrm{CW})$, and weight $(\mathrm{W})$ for Callinectes amnicola.

\begin{tabular}{lccc}
\hline Sex & $\begin{array}{c}\text { Carapace } \\
\text { length }(\mathbf{c m})\end{array}$ & $\begin{array}{c}\text { Carapace } \\
\text { width }(\mathbf{c m})\end{array}$ & Weight $(\mathrm{g})$ \\
\hline Male & $5.78 \pm 0.11^{*}$ & $12.63 \pm 0.25$ & $122.61 \pm 7.40^{* *}$ \\
Female & $5.34 \pm 0.19$ & $11.68 \pm 0.49$ & $89.65 \pm 8.84$ \\
\hline \multirow{2}{*}{ Total } & $5.61 \pm 0.10$ & $12.26 \pm 0.25$ & $\begin{array}{c}109.93 \pm 6.06 \\
(19.80-\end{array}$ \\
& $(3.50-7.00)$ & $(7.50-15.00)$ & $190.30)$ \\
\hline
\end{tabular}

Each value represents Mean \pm SE. Values in brackets represent ranges. ${ }^{*} p<0.05 ;{ }^{* *} p<0.01$ significant different with t-test.

No infection was found in the size group 8.5$11.5 \mathrm{~cm}$ and the number of ectoparasites ranged from 2 to 9 per crab. The mean condition factor for the parasitized male crabs for size class $11.6-13.5 \mathrm{~cm}(72.17 \pm 2.74)$ is higher than for all males of similar size class $(68.00 \pm 2.85)$ (Figure 2), while that for size class $13.6-16.5 \mathrm{~cm}(60.64 \pm 3.77)$ is lower than for all males of similar size class (64.37 \pm 3.85$)$.

Manganese (11.941 $\pm 1.538 \mathrm{ppm})$ recorded the highest mean trace metal value followed in order by Zinc (6.389 $\pm 0.905 \mathrm{ppm})$, Lead (0.054 $\pm 0.020 \mathrm{ppm})$, Cadmium $(0.009 \pm 0.001 \mathrm{ppm})$ and Mercury $(0.004 \pm 0.001 \mathrm{ppm})$ for C. amnicola (Table 4). Similar results were obtained for water and sediment. 
Table 2: Growth pattern of Callinectes amnicola using the relationship between weight (W) and carapace length (CL)

\begin{tabular}{llllll}
\hline Sex & $\begin{array}{l}\text { Regression equation } \\
(\log W=\log a+b \log C L)\end{array}$ & $\mathbf{R}^{2}$ & Growth pattern & $\begin{array}{l}\mathbf{t}_{\text {(sex) value }} \\
\left(\boldsymbol{H}_{0}: b=3\right)\end{array}$ & $\begin{array}{l}\mathbf{F}_{\text {(size group) }} \\
\text { value }\end{array}$ \\
\hline Male & $\log W=-0.21+2.98 \mathrm{Log} C L$ & 0.66 & Isometry & -0.74 & $0.01^{*}$ \\
Female & $\log W=-0.30+3.05 \mathrm{LogCL}$ & 0.93 & Positive allometry & $2.37^{*}$ & 0.42 \\
\hline All & $\log W=-0.33+3.12 \operatorname{LogCL}$ & 0.82 & Positive allometry & $7.28^{*}$ & $0.02^{*}$ \\
\hline
\end{tabular}

Table 3: Growth pattern of Callinectes amnicola using the relationship between weight (W) and carapace width (CW)

\begin{tabular}{llllll}
\hline Sex & $\begin{array}{l}\text { Regression equation } \\
(\log W=\log a+b \log C W)\end{array}$ & $R^{2}$ & Growth pattern & $\begin{array}{l}t_{\text {(sex) value }} \\
\left(H_{0}: b=3\right)\end{array}$ & $\begin{array}{l}F_{\text {(size group) }} \\
\text { value }\end{array}$ \\
\hline Male & $\log W=-1.18+2.95 \log C W$ & 0.74 & Negative allometry & $-3.05^{*}$ & 0.35 \\
Female & $\operatorname{LogW}=-0.82+2.57 \mathrm{LogCW}$ & 0.90 & Negative allometry & $-28.59^{*}$ & 0.35 \\
\hline All & LogW $=-1.05+2.81 \mathrm{LogCW}$ & 0.83 & Negative allometry & $-16.89^{*}$ & 0.26 \\
\hline
\end{tabular}

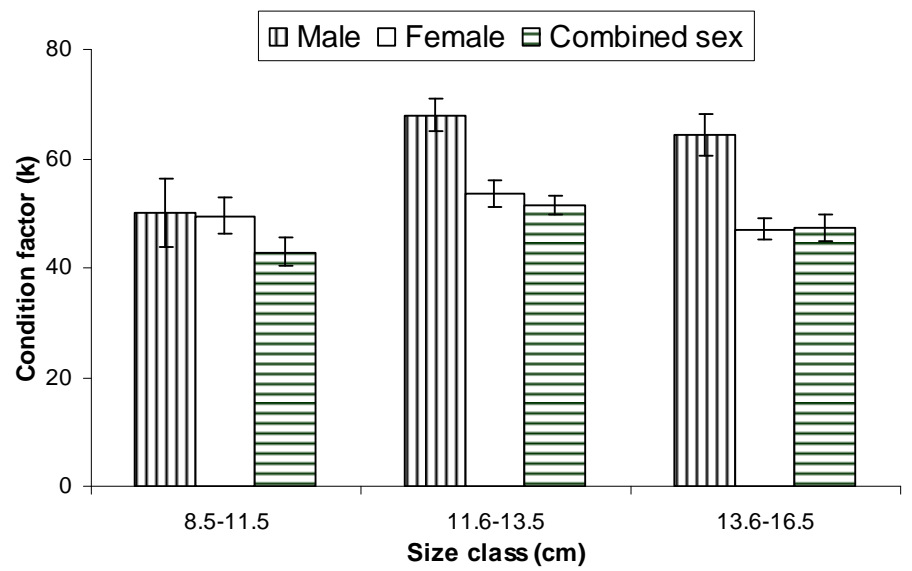

Figure 1: Condition factor of Callinectes amnicola for each sex, combined sex and different size classes.

However, for each trace metal except Lead, C. amnicola recorded the highest mean value compared to sediment and water. The gill had the highest mean values for all trace metals measured (Table 5), with the highest recorded for $\mathrm{Mn}(22.351 \pm 4.384 \mathrm{ppm})$ and the lowest for $\mathrm{Hg}$ $(0.008 \pm 0.002 \mathrm{ppm})$. Aside gills, cheliped recorded significantly higher mean values for $\mathrm{Cd}$
$(0.010 \pm 0.002 \mathrm{ppm})$ compared to testis and ovary. For all trace metals, the mean level for ovary is lower than for testis.

Gills of C. amnicola had the highest bioconcentration factor from sediment and water for all the metals studied (Table 6); $\mathrm{Pb}$ was bioaccumulated by a factor of 21 and 42 from sediment and water respectively, while $\mathrm{Hg}$ was 
bioaccumulated by a factor of 2 and 5 from sediment and water respectively. The ovary did not show bioaccumulation of any trace metals; however testis recorded bioaccumulation from water only for $\mathrm{Mn}, \mathrm{Zn}$ and $\mathrm{Hg}$ by a factor of 2 to 3 .

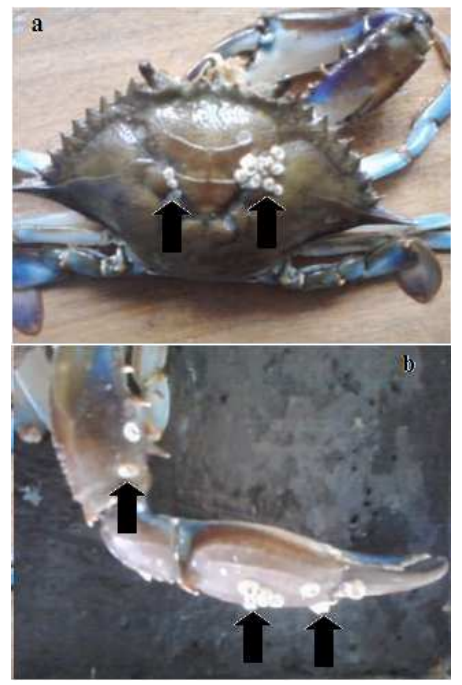

Plate 2: Ectoparasitic barnacles on the (a) carapace and (b) cheliped of infected crabs.

Muscle tissue, cheliped and carapace showed bioaccumulation from water by a factor of 2 to 4 for all metals studied except for $\mathrm{Hg}$. For the whole crab, Zinc was the most bioaccumulated trace metal from water with a factor of 11 followed in order by $\mathrm{Mn}, \mathrm{Cd}, \mathrm{Pb}$ and $\mathrm{Hg}$ by factors ranging from 2 to 4 (Figure 3). However, for sediment samples, only $\mathrm{Zn}$ and $\mathrm{Pb}$ were bioaccumulated by factors of 5 and 2 respectively.

\section{Discussion}

The male-female sex ratio recorded during the study was not significant suggesting that both sexes were equally abundant. This agrees with reports of $[1 ; 5]$ although the former author observed deviations from the expected ratio during the peak spawning months. However, [7] reported a statistically different male to female sex ratio, with the males significantly higher than the females.

The maximum carapace length, carapace width and weight recorded for $C$. amnicola from Lagos Lagoon are $7.00 \mathrm{~cm}, 15.00 \mathrm{~cm}$ and $190.30 \mathrm{~g}$ respectively. Maximum size of $16.60 \mathrm{~cm}$ carapace length, $30.00 \mathrm{~cm}$ carapace width and a weight of $348.50 \mathrm{~g}$ have been reported from the lagoons and adjacent creeks of southwestern Nigeria [7]. Udoh [14] reported a maximum size of $16.64 \mathrm{~cm}$ carapace width and average size at maturity of $9.27 \mathrm{~cm}$ carapace width for C. amnicola in Imo River Estuary, Nigeria. The mean carapace width for this study $(12.26 \pm 0.25 \mathrm{~cm})$ suggests that they are matured specimens. Abowei et al. [3] reported relatively larger size of $C$. amnicola from Southwest Nigeria compared to Okpoka Creek, Niger Delta and attributed this to high fishing mortality. Abowei et al. [13] opine that the excessive fishing pressure due to human exploitation of $C$. amnicola in Okpoka Creek is not sustainable. There were significant differences among the sexes for carapace length and weight but not for carapace width; with the males longer and heavier than the females. These features may be used to discriminate between the sexes.

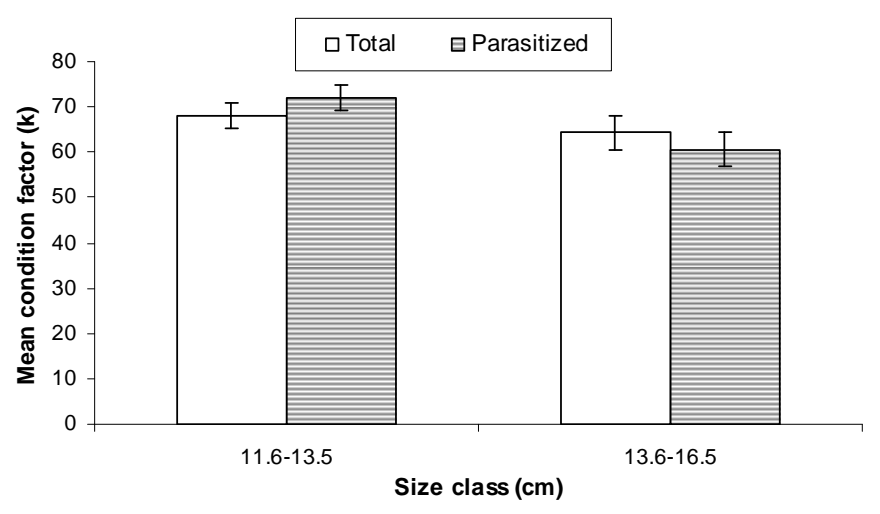

Figure 2: Condition factors of male Callinectes amnicola infected by ectoparasites and total males (infected +non-infected) for the two parasitized size classes. 
Table 4: Trace metal concentration in Callinectes amnicola, water and sediment from Lagos Lagoon.

\begin{tabular}{lccccc}
\hline Host/Medium & $\mathrm{Mn}(\mathrm{ppm})$ & $\mathrm{Zn}(\mathrm{ppm})$ & $\mathrm{Pb}(\mathrm{ppm})$ & $\mathrm{Cd}(\mathrm{ppm})$ & $\mathrm{Hg}(\mathrm{ppm})$ \\
\hline $\begin{array}{l}\text { Callinectes } \\
\text { amnicola }\end{array}$ & $11.941 \pm 1.538^{\mathrm{b}}$ & $6.389 \pm 0.905^{\mathrm{b}}$ & $0.054 \pm 0.020^{\mathrm{a}}$ & $0.009 \pm 0.001^{\mathrm{b}}$ & $0.004 \pm 0.001^{\mathrm{b}}$ \\
Water & $4.925 \pm 3.061^{\mathrm{a}}$ & $2.607 \pm 1.609^{\mathrm{a}}$ & $0.007 \pm 0.004^{\mathrm{a}}$ & $0.003 \pm 0.001^{\mathrm{a}}$ & $0.002 \pm 0.001^{\mathrm{a}}$ \\
Sediment & $9.732 \pm 1.000^{\mathrm{a}}$ & $4.597 \pm 0.724^{\mathrm{a}}$ & $0.011 \pm 0.003^{\mathrm{a}}$ & $0.008 \pm 0.004^{\mathrm{a}}$ & $0.004 \pm 0.001^{\mathrm{a}}$ \\
\hline
\end{tabular}

Each value is Mean $\pm \mathrm{SE}$. Means with the same column superscript are not significantly different.

Table 5: Trace metal concentration in different parts of Callinectes amnicola from Lagos Lagoon.

\begin{tabular}{lccccc}
\hline \multicolumn{1}{c}{ Organs } & $\mathrm{Mn}(\mathrm{ppm})$ & $\mathrm{Zn}(\mathrm{ppm})$ & $\mathrm{Pb}(\mathrm{ppm})$ & $\mathrm{Cd}(\mathrm{ppm})$ & $\mathbf{H g}(\mathrm{ppm})$ \\
\hline Gill & $22.351 \pm 4.384^{\mathrm{b}}$ & $13.377 \pm 2.651^{\mathrm{b}}$ & $0.209 \pm 0.063^{\mathrm{b}}$ & $0.015 \pm 0.002^{\mathrm{c}}$ & $0.008 \pm 0.002^{\mathrm{b}}$ \\
Muscle & $9.069 \pm 0.422^{\mathrm{a}}$ & $5.180 \pm 0.294^{\mathrm{a}}$ & $0.013 \pm 0.002^{\mathrm{a}}$ & $0.007 \pm 0.000^{\mathrm{ab}}$ & $0.001 \pm 0.000^{\mathrm{a}}$ \\
Cheliped & $12.107 \pm 2.559^{\mathrm{a}}$ & $4.715 \pm 0.366^{\mathrm{a}}$ & $0.015 \pm 0.002^{\mathrm{a}}$ & $0.010 \pm 0.002^{\mathrm{bc}}$ & $0.003 \pm 0.001^{\mathrm{a}}$ \\
Carapace & $9.352 \pm 0.220^{\mathrm{a}}$ & $4.852 \pm 0.281^{\mathrm{a}}$ & $0.011 \pm 0.001^{\mathrm{a}}$ & $0.008 \pm 0.001^{\mathrm{ab}}$ & $0.002 \pm 0.000^{\mathrm{a}}$ \\
Ovary & $1.573 \pm 0.437^{\mathrm{a}}$ & $1.228 \pm 0.153^{\mathrm{a}}$ & $0.004 \pm 0.002^{\mathrm{a}}$ & $0.003 \pm 0.002^{\mathrm{a}}$ & $0.002 \pm 0.001^{\mathrm{a}}$ \\
Testis & $6.959 \pm 1.281^{\mathrm{a}}$ & $3.837 \pm 0.445^{\mathrm{a}}$ & $0.006 \pm 0.005^{\mathrm{a}}$ & $0.004 \pm 0.003^{\mathrm{a}}$ & $0.004 \pm 0.001^{\mathrm{a}}$ \\
\hline
\end{tabular}

Each value is Mean \pm SE. Means with the same column superscript are not significantly different.

Table 6: Bioconcentration factors $\left(\mathrm{BCF}_{\mathrm{s}}\right.$ and $\left.\mathrm{BCF}_{\mathrm{w}}\right)$ of trace metals in different parts of Callinectes amnicola from Lagos Lagoon in relation to sediment and water.

\begin{tabular}{lccccc}
\hline \multicolumn{1}{c}{ Organs } & Mn & $\mathbf{Z n}$ & $\mathbf{P b}$ & $\mathbf{C d}$ & $\mathbf{H g}$ \\
\hline Gill & $2.31^{\mathrm{c}}(7.63)^{\mathrm{b}}$ & $3.00^{\mathrm{b}}(8.15)^{\mathrm{b}}$ & $20.71^{\mathrm{b}}(42.44)^{\mathrm{b}}$ & $2.52^{\mathrm{a}}(5.58)^{\mathrm{b}}$ & $2.14^{\mathrm{b}}(5.28)^{\mathrm{b}}$ \\
Muscle & $0.94^{\mathrm{ab}}(2.99)^{\mathrm{ab}}$ & $1.14^{\mathrm{a}}(3.33)^{\mathrm{ab}}$ & $1.34^{\mathrm{a}}(2.85)^{\mathrm{a}}$ & $1.17^{\mathrm{a}}(2.88)^{\mathrm{ab}}$ & $0.36^{\mathrm{a}}(0.89)^{\mathrm{a}}$ \\
Cheliped & $1.29^{\mathrm{bc}}(3.33)^{\mathrm{ab}}$ & $1.06^{\mathrm{a}}(2.78)^{\mathrm{ab}}$ & $1.48^{\mathrm{a}}(2.89)^{\mathrm{a}}$ & $1.87^{\mathrm{a}}(3.71)^{\mathrm{ab}}$ & $0.70^{\mathrm{a}}(1.61)^{\mathrm{a}}$ \\
Carapace & $0.98^{\mathrm{ab}}(3.02)^{\mathrm{ab}}$ & $1.09^{\mathrm{a}}(2.93)^{\mathrm{ab}}$ & $1.09^{\mathrm{a}}(2.34)^{\mathrm{a}}$ & $1.24^{\mathrm{a}}(2.88)^{\mathrm{ab}}$ & $0.58^{\mathrm{a}}(1.3)^{\mathrm{a}}$ \\
Ovary & $0.16^{\mathrm{a}}(0.61)^{\mathrm{a}}$ & $0.28^{\mathrm{a}}(0.70)^{\mathrm{a}}$ & $0.32^{\mathrm{a}}(0.56)^{\mathrm{a}}$ & $0.67 \mathrm{a}(0.88)^{\mathrm{a}}$ & $0.43^{\mathrm{a}}(1.17)^{\mathrm{a}}$ \\
Testis & $0.74^{\mathrm{ab}}(2.04)^{\mathrm{ab}}$ & $0.84^{\mathrm{a}}(2.55)^{\mathrm{ab}}$ & $0.49^{\mathrm{a}}(0.67)^{\mathrm{a}}$ & $0.92^{\mathrm{a}}(1.13)^{\mathrm{a}}$ & $0.97^{\mathrm{a}}(2.50)^{\mathrm{ab}}$ \\
\hline
\end{tabular}

Each value is Mean $\pm \mathrm{SE}$. Water BCF values $\left(\mathrm{BCF}_{\mathrm{w}}\right)$ are in brackets. Means with the same column superscript are not significantly different.

C. amnicola showed negative allometric growth, using carapace width, regardless of sex or size; however, with carapace length, the crab exhibits isometric growth for male and positive allometric growth for female and sex combined. C. amnicola has been reported to exhibit positive allometric growth [7], negative allometric growth [10], positive allometric growth for male and negative allometric growth for female and sex combined [5]. 


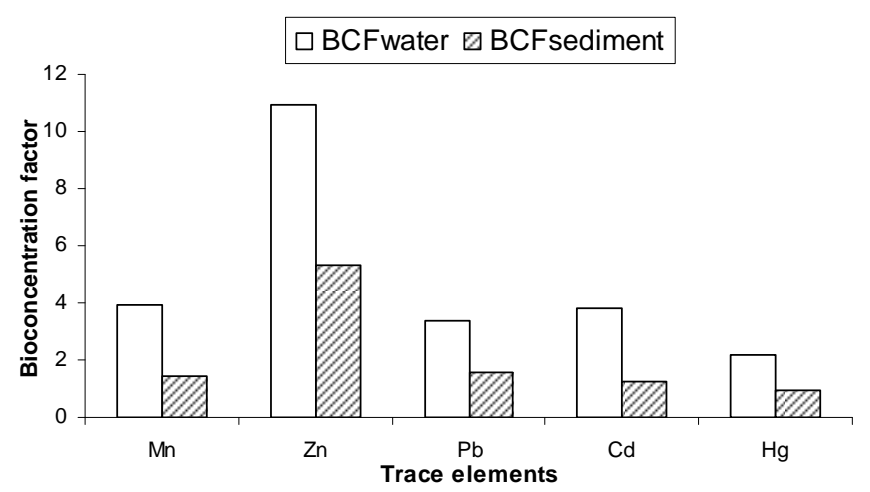

Figure 3: Bioconcentration factors $\left(\mathrm{BCF}_{\mathrm{s}}\right.$ and $\left.\mathrm{BCF}_{\mathrm{w}}\right)$ of trace metals in Callinectes amnicola from Lagos Lagoon in relation to sediment and water.

This study suggests that the $b$ estimate using carapace length may also be used to discriminate between sex and size of $C$. amnicola. Males were better conditioned than females and condition increased with higher size class; this strongly supports the report by Emmanuel [7], who attributed the lower condition factor of females to weight loss from spawning.

Although, Arimoro and Idoro [5] reported that condition factor did not vary with size and sex but showed seasonal variation, however, similarity in condition factor for both sexes independent of season was reported [10] and was attributed to ovigerous females and to utilization of food resources by the crab resulting in the accumulation of large quantities of flesh.

Only the male crabs of higher size classes were infected with ectoparasites; this may suggest that males adopt a more sedentary life compared to females. Ololade et al [25] opined that male crabs are more resident, especially in low salinity areas while females exhibit seasonal migratory behaviour for reproductive purposes. The prevalence of $13.46 \%$ for male crabs suggests a low infection rate. Parasitized males for the 11.6$13.5 \mathrm{~cm}$ size class were better conditioned than all the males for that size group put together, however, parasitized males for 13.616.5 size group had a lower mean condition factor compared to all males for that size group. This suggests that the ectoparasitic barnacles select better conditioned crabs for infestation and this colonization subsequently reduces the condition of such crabs as they grow. Apart from barnacle infestation affecting the condition of the crabs, it may also create an aesthetic problem that will indirectly affect their market values.

Living organisms require trace amounts of some heavy metals; some of these metals may be essential for animal tissue metabolism but may be hazardous for human metabolism especially when their concentration is high [26]. Trace metals such as cadmium, lead and mercury have no known beneficial effect on organisms and their accumulation over time in the bodies of mammals can cause serious illness [27]. Aquatic organisms have been reported to be selective in metal accumulation due to toxicity effects [28]. Heavy metals are taken from the surrounding environment through the gills or through the intestinal wall with ingestion of metals absorbed in the food. These characteristics provide an integration of both water and sediment derived pollutant stress giving rise to different bioconcentration factors in the different body parts of aquatic organisms. Mean trace metal values recorded for $C$. amnicola is in the order $\mathrm{Mn}>\mathrm{Zn}>\mathrm{Pb}>\mathrm{Cd}>\mathrm{Hg}$. This order was similar for water and sediment, although the crab recorded the highest value while the lowest was recorded for water. This shows that trace metal levels in C. amnicola reflects environmental conditions. $\mathrm{Mn}$ and $\mathrm{Zn}$ are micronutrients required for growth while $\mathrm{Pb}, \mathrm{Cd}$ and $\mathrm{Hg}$ are nonessential trace 
elements. Callinectes spp recorded the highest level of nickel, zinc and cadmium of all eleven edible arthropods studied in Southwestern Nigeria [9], and were attributed to ecological or metabolic factor. The mean levels recorded for this study did not exceed the WHO permissible level; this agrees with the reports of Lawal-Are and Kusemiju [6] and Banjo etla. [9]. However, [29] recorded consistently higher lead values than the $2.00 \mu \mathrm{g} / \mathrm{g}$ WHO permissible level in foods with lead showing the widest distribution of the four heavy metals studied $(\mathrm{Zn}, \mathrm{Cr}, \mathrm{Pb}$ and $\mathrm{Cd})$.

The gills had the highest mean values for all the trace metals measured. This is because the gills are constantly in contact with water as they play respiratory and excretory roles. Apart from the gills, cheliped recorded significantly higher mean $\mathrm{Cd}$ values compared with the ovary and testis. The mean levels of all trace metals recorded for ovary is lower than for testis. Fleshy tissues of crabs are good accumulators of heavy metals and the nutritional implication of this is that consumers of the animal may be exposed to heavy metal toxicity if bioaccumulation results due to regular consumption [30]. Some researchers have studied seasonal and sexual differences in the distribution of trace metals and reported higher levels of Chromium, Zinc, Lead, Iron and Manganese in $C$. amnicola flesh and eggs during the dry season [6] and although consistently higher Zinc levels in all female parts studied (abdomen, muscle and thorax) was reported [29], there was no significant difference in the distribution of metals between sexes.

The gills of $C$. amnicola had the highest bioconcentration factor for all trace elements with $\mathrm{Pb}$ bioaccumulated by a factor of 21 and 42 from sediment and water respectively. Since the gills are not edible, bioaccumulation in them will not affect humans through consumption. Otitoloju et al. [31] reported the toxicity of Copper and Lead to C. amnicola; sublethal concenterations of these trace metals resulted in their bioaccumulation in the tissues with gill>muscle>hepatopancreas, and a reduction in the weight of the exposed blue crab over a 14 day period was also reported. This suggests that the gills $C$. amnicola can be used to evaluate the bioavailabtlity of Lead in the aquatic environment.

This study shows that male $C$. amnicola were longer and heavier compared to females. The crabs can be discriminated with regards to sex through their growth pattern, condition factor and ectoparasitic infestation. The presence of ectoparasites was related to the condition of males. Mean trace metal values recorded for C. amnicola, water and sediment were in the order

Manganese $>$ Zinc $>$ Lead $>$ Cadmium $>$ Mercury; and were lower compared to WHO limits. The non-edible portion of the crab (gills) bioconcentrated lead by a factor of 42 from water, while the edible portion (muscle, chelipeds and carapace) bioaccumulated Manganese, Zinc and Cadmium from water by a maximum factor of 4 . C. amnicola may be used to monitor the bioavailability of trace metals in the Lagos Lagoon.

\section{References}

1. Lawal-Are A.O. 2010. Reproductive biology of the blue crab Callinectes amnicola (DeRochebrune) in the Lagos Lagoon, Nigeria. Turkish Journal of Fisheries and Aquatic Sciences 10: 1-7.

2. Guillory V. 2001. A review of incidental fishing mortalities of blue crabs. p. 28-41 In: Guillory V., Perry H.M. and Vanderkooy S. (eds), Proceedings of the Blue Crab Mortality Symposium. Gulf States Marine Fisheries Commission, Ocean Springs, Mississippi.

3. Abowei J.F.N., and George A.D.I. 2010. The morphology, abundance, size and sex distribution of Callinectes amnicola (DeRochebrune, 1883) from Okpoka Creek, Niger Delta, Nigeria. Current Research Journal of Biological Sciences 2(1): 27-34.

4. Emmanuel B.E. and Ogunwenmo C.A. 2010. The macrobenthos and the fishes of a tropical estuarine creek in Lagos, Southwestern Nigeria. Report and Opinion 2(1): 1-8.

5. Arimoro F.O. and Idoro B.O. 2007. Ecological studies and biology of Callinectes amnicola (Family Portunidae) in the lower reaches of Warri River, Delta 
State, Nigeria. World Journal of Zoology 2(2): $57-66$

6. Lawal-Are A.O. and Kusemiju K. 2006. Trace metals in the blue crab, Callinectes amnicola (DeRochebrune) of Lagos Lagoon, Nigeria. Nigerian Journal of Fisheries 3(2): 372-385.

7. Emmanuel B.E. 2008. The fishery and bionomics of the swimming crab Callinectes amnicola (DeRocheburne, 1883) from a tropical lagoon and its adjacent creek, Southwest, Nigeria. Journal of Fisheries and Aquatic Science 3(2): 114-125.

8. Lawal-Are A.O. 2009. Food and feding habits of the blue crab Callinectes amnicola (DeRochebrune) from three different interconnecting lagoons in Southwest Nigeria. European Journal of Scientific Research 32(1): 88-94.

9. Banjo A.D., Lawal O.A., Fasunwon B.T. and Alimi G.O. 2010. Alkali and heavy metal contaminants of some selected edible arthropods in southwestern Nigeria. American-Eurasian Journal of Toxicological Sciences 2(1): 25-29.

10. Abowei J.F.N. and George A.D.I. 2009. A study of the length-weight relationship and condition factor of Callinectes amnicola (DeRochebrune, 1883) fromOkpoka Creek, Niger Delta, Nigeria. International Journal of Animal and Veterinary Advances 1(2): 66-72.

11. George A.D.I. and Abowei J.F.N. 2009. The composition, ranking and diversity of Callinectes amnicola (DeRochebrune, 1883) food from Okpoka Creek, Niger Delta, Nigeria. Advance Journal of Food Science and Technology 1(1): 12-18.

12. George A.D.I., Abowei J.F.N. and InkoTariah M.B. 2009. The composition in different size groups and index of relative importance (IRI) of Callinectes amnicola (DeRochebrune, 1883) food from Okpoka Creek, Niger Delta, Nigeria. International Journal of Animal and Veterinary Advances 1(2): 83-91.

13. Abowei J.F.N., George A.D.I. and Davies O.A. 2010. Mortality, exploitation rate and recruitment pattern of Callinectes amnicola (DeRochebrune, 1883) from Okpoka Creek, Niger Delta, Nigeria. Asian
Journal of Agricultural Sciences 2(1): 2734.

14. Udoh J.P., Nlewadim A.A. and Ofor C. 2009. Maturity estimation inmale swimming brachyuran crab, Callinectes amnicola (DeRochebrune, 1883) (Decapoda, Portunidae) in the Imo River estuary, Nigeria. Nigerian Journal of Agriculture, Food and Environment 5(2-4): 61-71.

15. Lawson E.O., Akintola S.O. and Olatunde O.A. 2010. Aspects of the biology of sickle fin mullet, Liza falcipinnis (Valenciennes, 1836) from Badagry Creek, Lagos, Nigeria. Nature and Science 8(11): 1-15.

16. Uabol-Egbenni P.O., Okolie P.N., Famuyiwa O. and Teniola O. 2010. The significance of pathogenic bacteria in the gut of swimming crab Callinectes $\mathrm{sp}$ obtained from Lagos Lagoon and market samples stored at freezer temperature $\left(0^{\circ} \mathrm{C}\right)$. Pakistan Journal of Nutrition 9(4): 398-403.

17. Udoidiong O.M. 2010. Threats to species of epibenthic macrofauna of some mangrove wetlands in Eastern Obolo, Nigeria. World Journal of Applied Science and Technology 2(2): 232-244.

18. Barnes R.D. 1974. Invertebrate Zoology, 3rd edition. W. B. Saunders Company, Philadelphia, London. Toronto. pp. 510520, 579-610.

19. Bagenal T.B. 1978. Methods of Assessment of Fish Production in Freshwaters, 3rd edition. IBP Handbook No 3. pp. 126-130, 166-169.

20. Prendez M. and Carrasco M.A. 2003. Elemental composition of surface waters in the Antarctic Peninsula and interactions with the environment. Environmental Geochemistry and Health 25: 347-363.

21. Van Loon, J.C. 1980 Analytical Atomic Absorption Spectroscop:, Selected Methods. Academic Press, New York, 337pp.

22. Van Eeden, P.H. and Schoonbee H.J. 1991. Bioaccumulation of heavy metals by the freshwater crab Potamonautes warreni from a polluted wetland. South African Journal of Wildife Research 21(4):103108. 
23. Anderson J. 1974. A study of the digestion of sediment by the $\mathrm{HNO}_{3}-\mathrm{H}_{2} \mathrm{SO}_{4}$ and $\mathrm{HNO}_{3}-\mathrm{HCL}$ procedures. Atomic Absorption Newsletter 13(1):31-32.

24. Van Straalen, N.M. and Verkleij J.A.C. 1993. Leerboek Oecotoxicologie. VU. Uitgeverij, Amsterdam, 423pp.

25. Ololade I.A., Lajide L., Amoo I.A. and Oladoja N.A. 2008. Investigation of heavy metals contamination of edible marine sea food. African Journal of Pure and Applied Chemistry 2(12): 121-131.

26. Sheriff M.K., Awadallah R.M. and Mohamed A.E. 1979. Determination of trace elements of egyptian crops by neutron activation analysis: II. Trace elements in umbelliferae and legumirosae families. Journal of Radioanalytical and Nuclear Chemistry 53 (1-2): 145-151.

27. Hawkes S.J. 1997. What is a "Heavy Metal"? Jounal of Chemical Education 74(11):1374.
28. Ayodele J.T. and Abubakar M. 2002. Trace Metal Determination in Sediment and in two species of freshwater molluscs in Tiga Lake, Kano Nigeria. Nigerian Journal of Basic Applied Sciences 2(1): 81-90.

29. Olusegun A.O., Olukemi T.O. and Olukemi M.B. 2008. Heavy metal distribution in crab (Callinectes amnicola) living on the shores of Ojo Rivers, Lagos, Nigeria. The Environmentalist 29(1): 3336.

30. Goyer R.A. 1995. Nutrition and metal toxicity. American Journal of Clinical Nutrition 61(3 suppl.): 646S-650S.

31. Otitoloju A.A., Elegba O.K. and Osibona A.O. 2008. Biological responses in edible crab, Callinectes amnicola that couldserve as markers of heavy metal pollution. The Environmentalist 29(1): 37-46. 